\title{
The determination of the supportive care needs of patients diagnosed with cancer ${ }^{\star}$
}

\section{Kanser tanılı hastaların gereksinimlerinin belirlenmesi}

destekleyici

bakım

\author{
Hatice Tel Aydın ${ }^{1}$, Döne Guinnay ${ }^{2}$
}

\author{
Sivas Cumhuriyet Universitesi Sağlık Bilimleri Fakültesi Hemșirelik Bölümü, Sivas, Türkiye \\ 'Sivas Numune Hastanesi, Sivas, Türkiye \\ Corresponding author: Döne Günay, Sivas Numune Hastanesi, Sivas, Türkiye \\ E-mail: donegunay@gmail.com \\ Received/Accepted: November 12, 2019 /June 23, 2020 \\ Conflict of interest: There is not a conflict of interest.
}

\section{SUMMARY}

Objective: This study was conducted to determine the supportive care needs of individuals diagnosed with cancer.

Method: The descriptive study included 39 patients who were hospitalized in the 14-bed oncology clinic of a state hospital between May and July 2019 and agreed to participate in the study. The study data were obtained by face to face interview technique using the "Personel Information Form" and "James Supportive Care Screening".

Results: It was found that $30.7 \%$ of the patients were diagnosed with GIS cancers, $51.2 \%$ were in the 4 th stage of the disease, $12.8 \%$ had additional physical or mental disorders as well as cancer. $43.6 \%$ of the patients stated that the most distressing conditions for them were "the concern about whether there will be improvement" and "the possibility of recurrence of the disease". The mean score of supportive care needs of the patients was detected as 74. It was determined that the patients with the diagnosis of mental disorder had more social/practical problems and cognitive concerns, the total scale score and healthcare decision-making/communication subscale scores were higher, and the patients with the highest score in the spiritual concerns subscale were those in the 60-80 age group.

Conclusions: The supportive care needs of the patients with oncologic diagnosis are focused on lack of information, physical and emotional needs, and the patients experience distress most about the prognosis of the disease. In addition to the diagnosis of cancer, having mental health problems increases the supportive care needs of the patients. It is important for nurses to be aware of the supportive care needs of the patients diagnosed with cancer and to apply individual-specific and patient-centred care approach in terms of meeting the needs of the patients.

Keywords: Care, nursing, supportive care, supportive care needs, cancer
Hatice Tel Aydın

Döne Günay

ORCID IDs of the authors: H.T.A. 0000-0002-1518-8080 D.G. 0000-0002-8721-6028

\section{ÖZET}

Amaç: Bu çalışma kanser tanısı almış bireylerin destekleyici bakım gereksinimlerini belirlemek amacıyla yapıldı. Yöntem: Tanımlayıcı özelikteki araștırmaya, Mayıs-Temmuz 2019 tarihleri arasında, bir devlet hastanesinin 14 yataklı onkoloji kliniğinde yatmakta olan ve araştırmaya katılmayı kabul eden 39 hasta alındı. Araştırma verileri "Hasta Tanıtım Formu" ve "James Destekleyici Bakım Gereksinimlerini Belirleme Ölçeği” kullanılarak, yüz yüze görüşme tekniği ile elde edildi. 
Bulgular: Hastaların \% 30.7'sinde GİS kanserleri tanısın olduğu, \%51.2'sinin hastalığın 4. evresinde olduğu, \%12.8'inin kanser tanısı yanı sıra ek bir fiziksel ya da ruhsal hastalığa sahip olduğu saptandı. Hastaların \%43.5'i kendilerinde en fazla distres/sıkıntı yaratan durumun "iyileşme olup olmayacağı endişesi”" ve "hastalığın tekrarlama olasılığı" olduğunu ifade etti. Hastaların destekleyici bakım gereksinimi ölçek puanı ortalaması 74 olarak belirlendi. Ruhsal hastalık tanısı olan hastalarının sosyal ve bilișsel sorunları daha çok yaşadıkları, toplam ölçek puanı ve sağlık sorunları alt boyut puanlarının daha yüksek olduğu, manevi-dini konularla ilgili alt boyutta en yüksek puana sahip hastaların 60-80 yaş grubundaki hastalar olduğu belirlendi.

Sonuç: Onkolojik tanıya sahip hastaların destekleyici bakım gereksinimleri bilgi eksikliği, fiziksel ve duygusal gereksinimler noktasında yoğunlaşmakta olup, hastalar en fazla hastalığın prognozu hakkında distres yaşamaktadır. Kanser tanısına ek olarak ruhsal sağlık sorununa sahip olmak, hastaların destekleyici bakım gereksinimlerini arttırmaktadır. Hemşirelerin, kanser tanısı olan hastaların destekleyici bakım gereksinimlerinin farkında olarak, bireye özgü ve hasta merkezli bakım anlayışııı uygulamaları hasta gereksinimlerinin karşılanması açısından önemlidir.

Anahtar sözcükkler: Bakım, hemşirelik, destekleyici bakım, destekleyici bakım gereksinimi, kanser

* I. Uluslararası Kanser Günleri (1. UKG 19-21 Eylül 2019) sözel sunum.

"Makale için etik kurul izni; Sivas Cumhuriyet Üniversitesi Girişimsel Olmayan Klinik Araştırmalar Etik Kurulu'ndan 17.04.2019 tarih 2019-04/38 sayı ile alınmıştır"

\section{INTRODUCTION}

Individuals diagnosed with cancer face many difficulties in psychological, physical, social and spiritual areas starting from the moment they are diagnosed with the disease. Pain, difficulties in performing daily life activities, lack of information, economic difficulties, change in family relations, deterioration in spiritual processes and changes in sexual life constitute an important part of the problems related to cancer diagnosis and affect the patient negatively throughout the process ${ }^{1-5}$. In addition to causing a negative impact on the patient's quality of life, these problems experienced by the patients diagnosed with cancer also make it difficult for the patient to continue his / her life, can seriously prevent the continuation of the treatment, make it difficult to comply with the treatment and consequently affect the survival negatively ${ }^{6-8}$.

Diagnosis of cancer causes serious tension, anxiety and fear in both individuals and their family members. The process that begins with the diagnosis does not end even if the cancer treatment is successful, and cancer patients experience emotional distress due to the side effects of the treatment or the possibility of recurrence of the disease. The National Comprehensive Cancer Network (NCCN) considered the concept of "distress" as a less stigmatizing definition of hardship experienced by cancer patients, and the concept is used to express feelings and emotions that prevent an individual's ability to cope with cancer and that create a negative response in the individual, their physical symptoms and the way they are handled ${ }^{9}$. Distress is a multidimensional concept and the supportive care needs to prevent distress differ and vary depending on the individual. This diversity may be associated with the treatment of psychological and psychosocial conditions such as coping with the physical effects of cancer, anxiety, depression, ineffective coping with stress, feelings of isolation and spiritual distress ${ }^{10}$. The need for a patient-centred and comprehensive nursing care of the cancerdiagnosed individual and his / her family also increases significantly within the framework of the patient's supportive care needs ${ }^{11,12}$.

When there is a mismatch between the perceived needs of cancer patients and the suitability of the service provided, unmet needs arise ${ }^{3,13}$. Although the identification and treatment of distress is critical in coping situation of the patient, healthcare professionals may fail to identify the patients experiencing distress ${ }^{14}$. It is stated that nurses who work with cancer patients generally provide limited psychosocial care to the patients who express their distress and that the psychosocial needs of most patients are not met ${ }^{15}$. There are study results showing that unmet needs of the patients have a negative impact on the patients' well-being, welfare and coping with stress ${ }^{2,15}$, reduce their compliance with the treatment, contribute to physical and psychological morbidity and distress, increase disability, reduce chances of survival, and impose financial burden on the national health system ${ }^{12,16}$.

Patient-centred care is considered as an indicator of the provision of quality health care to the patients diagnosed with cancer ${ }^{17}$. Supportive care is seen as an approach that contributes to patient-centred care model. Supportive care can be defined as comprehensive patient-oriented care that helps the individual diagnosed with cancer and his/her family to cope with the diagnosis and treatment of cancer and that should be provided in all processes from prediagnosis to definitive diagnosis and treatment process, recovery or terminal period and death ${ }^{18,19}$. Some measures such as learning the 
treatment and care plan, meeting with health care professionals, access to evidence-based information, providing assistance with situations such as emotion-oriented support and transport, home activities, procurement of supports and prostheses throughout the cancer experience are considered as part of the supportive care needs $[2,16,19,20]$

The care provided to the patients diagnosed with cancer should not be limited to the provision of anti-cancer treatment, but also nurses working in oncology services should be able to meet the supportive care needs of the patients ${ }^{20}$. Planning and implementing patient-specific care in accordance with the identified needs will reduce the patient's distress, poor quality of life, dissatisfaction with care, and prevent the increase in healthcare use and cost ${ }^{12,20}$. Identifying the supportive care needs of the patients is stated to be able to provide impetus for redesigning services and developing resources for people with cancer $16,21,22$. It is the responsibility of nursing services to identify and manage the supportive care needs in the care of cancer patients ${ }^{11,23}$. There are a limited number of studies conducted in our country to identify these needs. In this study, it was aimed to determine the supportive care needs of the patients diagnosed with cancer and some related factors. It is thought that the data obtained will contribute to identify the problems and distress experienced by cancer patients with a holistic perspective and to raise awareness about supportive care needs.

\section{MATERIAL AND METHODS}

The study included 39 adult patients hospitalized in the oncology clinic with a capacity of 14 beds in a state hospital between May and July 2019 and volunteered to participate in the study. The number of patients who accepted to participate in the study constituted $75 \%$ (39/52) of the total 52 patients who were hospitalized within the specified date range. Ethics committee approval was obtained for the study and written permission was obtained from the Provincial Health Directorate to which the hospital where the research would be conducted was affiliated. Permission was obtained from the author via e-mail for the James Supportive Care Screening used in the study. The purpose of the study was explained to all patients by the researcher and informed consent was obtained from the patients who agreed to participate in the study. The study data were collected with the Personel Information Form and James Supportive Care Screening. The participants were asked to answer the questions in the data collection forms completely and the forms were applied by face to face interview method. The data obtained from the study were recorded and analysed using SPSS 22.0 program. Since parametric test assumptions were fulfilled in the evaluation of the data, the significance test was used for the difference between two means in independent groups when comparing the measurements obtained with respect to one variable obtained by measurement; variance analysis was used when comparing the measurements obtained from more than two independent groups with respect to one variable obtained by measurement, and the error level was taken as $\mathrm{p}<0.05$.

Personel Information Form: This form prepared by the researchers by examining the related literature includes questions that assess the sociodemographic characteristics of the patients (age, gender, marital status, educational status, occupation, income level, the state of having child, living with whom), some basic characteristics related to their diseases (diagnosis, disease stage, presence of additional physical and mental disorders) and the most distressing conditions.

James Supportive Care Screening: The James Supportive Care Screening is a scale that can be used in every stage and treatment of cancer with its 6 subscales, developed by Wells-Di Gregorio et al. (2013) in order to determine the distress experienced by individuals diagnosed with cancer in the last week and in which area support is needed [17]. The subscales of the scale are as follows: emotional concerns, spiritual concerns, healthcare decision-making/communication, social/practical problems, cognitive concerns, physical symptoms. The scale is scored as none (0), mild (1), moderate (2) and severe (3). Scale questions can be evaluated by scoring one by one or over the total score. The highest total score that can be obtained from the scale is 144 and the lowest score is 0 (zero). The total scale score and the score of the subscales reflect the level of supportive care needs. As the total score increases in the James Supportive Care Screening, the level of supportive care needs increases. In our country, the validity and reliability studies of the scale were conducted by Demirkol and Çam in 2016, and the Cronbach's alpha value was set as $0.91^{24}$. The Cronbach's alpha coefficient was calculated as 0.93 in our study. 


\section{RESULTS}

It was found that $56.4 \%$ of the patients participated in the study were male, $53.8 \%$ were between the ages of $60-80,64.1 \%$ were literate or primary school graduates, $82.0 \%$ were married, $43.5 \%$ were not working, $76.9 \%$ stated that their income and expense status are equivalent, $82.0 \%$ had child and lived with their families. It was determined that $30.7 \%$ of the patients were diagnosed with gastrointestinal system cancers (colorectal, pancreas, stomach, liver), $51.2 \%$ were in stage IV, and the rates of not having any physical or mental disorders other than cancer were $87.1 \%$.

Of the patients who responded to questions aimed at identifying the concerns and problems experienced by cancer patients, $48.7 \%$ stated that they were concerned about their nutrition/diet, $30.7 \%$ stated that they were worried about how their family and friends would cope with this diagnosis, and $28.2 \%$ stated that they had difficulty in speaking/swallowing. $33.3 \%$ of the patients stated that they wanted to get information about nutrition and diet, $23.0 \%$ about how their family and friends would cope with this diagnosis, and $12.8 \%$ about difficulty in speaking and/or swallowing.

The expressions of the patients who participated in the study regarding the conditions that create the most emotional distress are given in Table 1.

Table 1: Distressing conditions in the patients

\begin{tabular}{|l|c|c|}
\hline Expressions & $\mathbf{n}$ & $\boldsymbol{\%}$ \\
\hline The fear of death & 4 & 10.3 \\
\hline Longing for family members & 9 & 23.0 \\
\hline Discomfort caused by interventional procedures (pain, hurt etc.) & 4 & 10.3 \\
\hline Worry-uncertainty about whether the disease process will improve or repeat & 17 & 43.5 \\
\hline Others * & 5 & 12.9 \\
\hline
\end{tabular}

* Worrying about burdening others, Failure to worship

The patients expressed the state of concernuncertainty about whether the disease process would improve or that the disease would recur $(43.5 \%)$ and longing for family members due to hospitalization $(23.0 \%)$ as the most distressing conditions for themselves.
The mean scores of the James Supportive Care Screening of the patients who participated in our study are presented in Table 2 .

Table 2: Mean Scores of the James Supportive Care Screening

\begin{tabular}{|l|c|c|c|}
\hline \multirow{2}{*}{$\begin{array}{c}\text { Supportive Care Needs Scale Sub- } \\
\text { Dimensions }\end{array}$} & \multicolumn{3}{c|}{ Scale Scores } \\
\cline { 2 - 4 } & Min - Max & Median & S.d. \\
\hline Emotional Needs & $0-42$ & 29 & 12.94 \\
\hline Spiritual Needs & $0-12$ & 8 & 4.82 \\
\hline $\begin{array}{l}\text { Healthcare Decision- } \\
\text { Making/Communication Needs }\end{array}$ & $0-12$ & 4 & 4.22 \\
\hline Social/Practical Needs & $0-18$ & 5 & 8.17 \\
\hline Cognitive Needs & $0-9$ & 3 & 3.38 \\
\hline Physical Needs & $0-51$ & 29 & 13.72 \\
\hline The Total Score & $0-145$ & 74 & 35.66 \\
\hline
\end{tabular}


It was found that the total score of supportive care needs of the patients included in the study was 74 \pm 35.66 , and the mean scores of healthcare decision-making/communication and social/ practical problems subscales were lower compared to other subscales.

The mean scores of the James Supportive Care Screening of the patients participating in the study were evaluated according to some sociodemographic and disease characteristics, and the results are given in Table 3.

In our study, it was determined that the total scores of supportive care needs of young patients were higher than other age groups, but there was no significant difference between the groups. It was observed that the health-related needs of female patients who participated in the study were higher than male patients and the difference was statistically significant $(p=0.036)$. There was no significant difference in the total scores of supportive care needs of the patients according to the characteristics such as marital status, education level, occupation, income level and having child. Supportive care needs were found to be higher in the patients with other physical health problems accompanying the diagnosis of cancer, but the difference between the groups was not significant.
It was determined that the patients with mental health problems accompanying the diagnosis of cancer had more supportive care needs and the difference between the groups was significant ( $\mathrm{p}$ $=0.044$ ).

When the patients' scores obtained from the subscales were evaluated, it was observed that the scores of university-level educated patients were higher in the emotional concerns subscale, the scores of the patients between the ages of $60-80$ were higher in the spiritual concerns subscale, the scores of the patients stating that they had mental health problems accompanying cancer were higher in the healthcare decision-making/communication subscale, the scores of female patients were higher in the social/practical problems subscale, the scores of the patients stating that they were living alone were higher in the cognitive concerns subscale, the scores of the patients stating that they had mental health problems accompanying cancer were higher in the physical symptoms subscale; supportive care needs of these patients were higher, but this difference was not statistically significant. 
Table 3. Comparison of Supportive Care Needs According to Some Characteristics of Patients

\begin{tabular}{|c|c|c|c|c|c|c|c|c|c|c|c|c|c|c|c|}
\hline & $\mathbf{n}$ & \multicolumn{2}{|c|}{$\begin{array}{c}\text { Supportive Care } \\
\text { Needs Total Scores } \\
\text { X } \pm \text { S.d. }\end{array}$} & \multicolumn{2}{|c|}{$\begin{array}{c}\text { Emotional Needs } \\
\text { Score } \\
X \pm \text { S.d. }\end{array}$} & \multicolumn{2}{|c|}{$\begin{array}{l}\text { Spiritual Needs } \\
\text { Score } \\
\mathrm{X} \pm \text { S.d. }\end{array}$} & \multicolumn{2}{|c|}{$\begin{array}{l}\text { Health Needs } \\
\text { Score } \\
X \pm \text { S.d. }\end{array}$} & \multicolumn{2}{|c|}{$\begin{array}{l}\text { Social Needs } \\
\text { Score } \\
X \pm \text { S.d. }\end{array}$} & \multicolumn{2}{|c|}{$\begin{array}{c}\text { Cognitive Needs } \\
\text { Score } \\
X \pm \text { S.d. }\end{array}$} & \multicolumn{2}{|c|}{$\begin{array}{l}\text { Physical Needs Score } \\
\qquad X \pm \text { S.d. }\end{array}$} \\
\hline \multicolumn{16}{|l|}{ Age } \\
\hline $18-38$ & 5 & 82 & 43.77 & 28.2 & 14.77 & 8.8 & 2.28 & 6.2 & 4.54 & 7.6 & 5.17 & 4.2 & 3.7 & 27 & 16.92 \\
\hline $39-59$ & 13 & 77.3 & 35.23 & 25.23 & 10.19 & 7.53 & 4.19 & 5 & 4 & 7.15 & 6.09 & 4.46 & 3.28 & 27.92 & 15.4 \\
\hline $60-80$ & 21 & 75.71 & 35.79 & 24.85 & 14.49 & 10.19 & 5.46 & 3.28 & 4.22 & 6.14 & 9.92 & 3.76 & 3.52 & 27.47 & 12.57 \\
\hline & & \multicolumn{2}{|c|}{$\begin{array}{c}\mathrm{F}=0.06 \\
\mathrm{p}=0.942\end{array}$} & \multicolumn{2}{|c|}{$\begin{array}{c}\mathrm{C}=0.13 \\
\mathrm{p}=0.878\end{array}$} & \multicolumn{2}{|c|}{\begin{tabular}{c|}
$\mathrm{T}=1.23$ \\
$\mathrm{p}=0.302$
\end{tabular}} & \multicolumn{2}{|c|}{$\begin{array}{c}\mathrm{F}=1.30 \\
\mathrm{p}=0.283\end{array}$} & \multicolumn{2}{|c|}{$\begin{array}{c}\mathrm{T}=1.30 \\
\mathrm{p}=0.910\end{array}$} & \multicolumn{2}{|c|}{$\begin{array}{l}\mathrm{F}=0.16 \\
\mathrm{p}=0.845\end{array}$} & \multicolumn{2}{|c|}{$\begin{array}{c}\mathrm{F}=0.01 \\
\mathrm{p}=0.991\end{array}$} \\
\hline \multicolumn{16}{|l|}{ Sex } \\
\hline Female & 17 & 84.88 & 31.9 & 29.41 & 10.48 & 8.47 & 2.71 & 5.82 & 4.12 & 9.17 & 10.36 & 4.05 & 3.03 & 27.94 & 12.72 \\
\hline Male & 22 & 71 & 37.92 & 22.31 & 14.01 & 9.63 & 5.99 & 3 & 3.95 & 4.72 & 5.47 & 4.04 & 3.7 & 27.27 & 14.74 \\
\hline & & \multicolumn{2}{|c|}{\begin{tabular}{c|}
$t$ \\
$\mathrm{t}=1.21$ \\
$\mathrm{p}=0.233$
\end{tabular}} & \multicolumn{2}{|c|}{$\begin{array}{c}\mathrm{I}=1.74 \\
\mathrm{p}=0.090\end{array}$} & \multicolumn{2}{|c|}{$\begin{array}{c}1 \\
\mathrm{t}=0.74 \\
\mathrm{p}=0.462\end{array}$} & \multicolumn{2}{|c|}{$\begin{array}{c}\mathrm{t}=2.17 \\
\mathrm{p}=0.036^{*}\end{array}$} & \multicolumn{2}{|c|}{$\begin{array}{l}1 \\
\mathrm{t}=1.73 \\
\mathrm{p}=0.092\end{array}$} & \multicolumn{2}{|c|}{$\begin{array}{c}1 \\
\mathrm{t}=0.14 \\
\mathrm{p}=0.882\end{array}$} & \multicolumn{2}{|c|}{$\begin{array}{c}\mathrm{l}=0.14 \\
\mathrm{p}=0.882\end{array}$} \\
\hline \multicolumn{16}{|l|}{ Marital status } \\
\hline Married & 32 & 78.5 & 36,5 & 25.71 & 12.89 & 9.25 & 5.09 & 4.53 & 4.05 & 7.28 & 8.64 & 3.96 & 3.2 & 27.75 & 14.08 \\
\hline Single & 7 & 70.42 & 33.58 & 24 & 14.14 & 8.57 & 3.64 & 2.85 & 5.01 & 3.85 & 5.08 & 4.42 & 4.39 & 26.71 & 12.94 \\
\hline & & \multicolumn{2}{|c|}{$\begin{array}{c}\mathrm{t}=1.21 \\
\mathrm{p}=0.594\end{array}$} & \multicolumn{2}{|c|}{$\begin{array}{c}1 \\
t=1.74 \\
p=0.765\end{array}$} & \multicolumn{2}{|c|}{$\begin{array}{c}\mathrm{I}=0.74 \\
\mathrm{p}=0.741\end{array}$} & \multicolumn{2}{|c|}{$\begin{array}{c}\mathrm{I} \\
\mathrm{t}=2.17 \\
\mathrm{p}=0.349\end{array}$} & \multicolumn{2}{|c|}{$\begin{array}{c}\mathrm{I} \\
\mathrm{t}=1.73 \\
\mathrm{p}=0.322\end{array}$} & \multicolumn{2}{|c|}{$\begin{array}{c}1 \\
\mathrm{t}=0.14 \\
\mathrm{p}=0.750\end{array}$} & \multicolumn{2}{|c|}{$\begin{array}{c}1 \\
\mathrm{t}=0.14 \\
\mathrm{p}=0.859\end{array}$} \\
\hline Education status & & & & & & & & & & & & & & & \\
\hline $\begin{array}{l}\text { Literate/ Primary } \\
\text { School }\end{array}$ & 25 & 72.84 & 35.32 & 24.28 & 12.59 & 9.44 & 5.73 & 3.84 & 4.2 & 6.4 & 9.26 & 3.88 & 3.43 & 25 & 13.26 \\
\hline Middle- high school & 10 & 81 & 42.68 & 25 & 15.52 & 8.8 & 2.97 & 5 & 4.92 & 7.3 & 6.73 & 4.2 & 3.91 & 30.7 & 15.46 \\
\hline University & 4 & 93.5 & 10.24 & 33.5 & 5.8 & 8 & 1.63 & 4.75 & 2.87 & 6.75 & 4.57 & 4.75 & 2.06 & 35.75 & 9.17 \\
\hline & & $\begin{array}{l}\mathrm{F}=0 \\
\mathrm{P}=0\end{array}$ & & $\begin{array}{r}\mathrm{F}=0 \\
\mathrm{P}=0 .\end{array}$ & & $\begin{array}{l}\mathrm{F}=\mathrm{C} \\
\mathrm{P}=0\end{array}$ & & $\begin{array}{l}\mathrm{F}=0 . \\
\mathrm{P}=0 .\end{array}$ & & $\begin{array}{r}\mathrm{F}=\mathrm{C} \\
\mathrm{P}=0\end{array}$ & & $\begin{array}{l}\mathrm{F}=0 . \\
\mathrm{P}=0.8\end{array}$ & & & \\
\hline Job & & & & & & & & & & & & & & & \\
\hline Retired & 11 & 62.09 & 34.66 & 19.18 & 15.28 & 8.72 & 3.58 & 2.18 & 3.54 & 3.45 & 5.73 & 2.63 & 3.32 & 25.9 & 15.68 \\
\hline
\end{tabular}




\begin{tabular}{|c|c|c|c|c|c|c|c|c|c|c|c|c|c|c|c|}
\hline Officer & 6 & 86.5 & 15.13 & 28.66 & 9.43 & 8 & 1.09 & 5 & 2.96 & 7.66 & 4.67 & 5 & 3.4 & 32.16 & 9.36 \\
\hline Worker & 5 & 69.6 & 46.2 & 25.4 & 13.86 & 10 & 12.18 & 2.8 & 3.89 & 4.4 & 3.04 & 4 & 3.53 & 23 & 15.01 \\
\hline Not working & 17 & 85.58 & 37.18 & 28.29 & 11.69 & 9.52 & 2.98 & 5.7 & 4.67 & 9.05 & 10.66 & 4.64 & 3.39 & 28.35 & 13.89 \\
\hline & & \multicolumn{2}{|c|}{$\begin{array}{c}\mathrm{F}=1.20 \\
\mathrm{p}=0.324\end{array}$} & \multicolumn{2}{|c|}{$\begin{array}{c}\mathrm{F}=1.28 \\
\mathrm{p}=0.295\end{array}$} & \multicolumn{2}{|c|}{$\begin{array}{c}F=0.21 \\
p=0.886\end{array}$} & \multicolumn{2}{|c|}{$\begin{array}{l}\mathrm{F}=1.95 \\
\mathrm{p}=0.139\end{array}$} & \multicolumn{2}{|c|}{$\begin{array}{c}\mathrm{F}=1.23 \\
\mathrm{p}=0.312\end{array}$} & \multicolumn{2}{|c|}{$\begin{array}{c}\mathrm{F}=0.97 \\
\mathrm{p}=0.418\end{array}$} & \multicolumn{2}{|c|}{$\begin{array}{c}\mathrm{F}=0.46 \\
\mathrm{p}=0.712\end{array}$} \\
\hline \multicolumn{16}{|l|}{ Income rate } \\
\hline Income less & 6 & 94.5 & 37.27 & 30.5 & 12.5 & 9.5 & 3.2 & 5.16 & 4.66 & 12.16 & 15.74 & 4 & 2.09 & 33.16 & 10.06 \\
\hline Income equivalent & 30 & 76.5 & 34.43 & 25.45 & 12.03 & 9.1 & 5.3 & 4.43 & 4.21 & 6.2 & 5.83 & 4.3 & 3.61 & 27 & 14.09 \\
\hline Income surplus & 3 & 47.66 & 36 & 14.66 & 21.07 & 8.66 & 3.05 & 0.33 & 0.57 & 0.33 & 0.57 & 1.66 & 2.88 & 22 & 17.32 \\
\hline & & \multicolumn{2}{|c|}{$\begin{array}{c}\mathrm{F}=1.81 \\
\mathrm{p}=0.178\end{array}$} & \multicolumn{2}{|c|}{$\begin{array}{c}F=1.53 \\
p=0.228\end{array}$} & \multicolumn{2}{|c|}{$\begin{array}{c}\mathrm{F}=0.03 \\
\mathrm{p}=0.970\end{array}$} & \multicolumn{2}{|c|}{$\begin{array}{l}\mathrm{F}=1.50 \\
\mathrm{p}=0.237\end{array}$} & \multicolumn{2}{|c|}{$\begin{array}{c}\mathrm{F}=2.49 \\
\mathrm{p}=0.097\end{array}$} & \multicolumn{2}{|c|}{$\begin{array}{c}\mathrm{F}=0.81 \\
\mathrm{p}=0.450\end{array}$} & \multicolumn{2}{|c|}{$\begin{array}{l}\mathrm{F}=0.076 \\
\mathrm{p}=0.474\end{array}$} \\
\hline \multicolumn{16}{|l|}{ Having a child } \\
\hline Yes & 32 & 78.5 & 35.41 & 25.71 & 13.32 & 9.25 & 4.89 & 4.53 & 4.17 & 7.28 & 8.67 & 3.96 & 3.33 & 27.75 & 13.51 \\
\hline No & 7 & 70.42 & 42.02 & 24 & 12.97 & 8.57 & 4.18 & 2.85 & 4.8 & 3.85 & 5.49 & 4.42 & 3.55 & 26.71 & 16.57 \\
\hline & & \multicolumn{2}{|c|}{$\begin{array}{c}\mathrm{t}=0.53 \\
\mathrm{p}=0.594\end{array}$} & \multicolumn{2}{|c|}{$\begin{array}{c}\mathrm{t}=0.31 \\
\mathrm{p}=0.765\end{array}$} & \multicolumn{2}{|c|}{$\begin{array}{l}\mathrm{t}=0.033 \\
\mathrm{p}=0.741\end{array}$} & \multicolumn{2}{|c|}{$\begin{array}{c}\mathrm{t}=0.94 \\
\mathrm{p}=0.349\end{array}$} & \multicolumn{2}{|c|}{$\begin{array}{c}\mathrm{t}=1.00 \\
\mathrm{p}=0.322\end{array}$} & \multicolumn{2}{|c|}{$\begin{array}{l}\mathrm{t}=0.032 \\
\mathrm{p}=0.750\end{array}$} & \multicolumn{2}{|c|}{$\begin{array}{c}\mathrm{t}=0.017 \\
\mathrm{p}=0.859\end{array}$} \\
\hline \multicolumn{16}{|l|}{ Living with whom } \\
\hline Single & 2 & 92 & 36.76 & 31 & 5.65 & 12 & 0 & 5.5 & 7.77 & 7.5 & 9.19 & 6 & 4.24 & 30 & 18.38 \\
\hline With family & 37 & 76.24 & 35.94 & 25.1 & 13.19 & 8.97 & 4.91 & 4.16 & 4.12 & 6.62 & 8.25 & 3.94 & 3.37 & 27.43 & 13.75 \\
\hline & & \multicolumn{2}{|c|}{$\begin{array}{c}\mathrm{t}=0.60 \\
\mathrm{p}=0.550\end{array}$} & \multicolumn{2}{|c|}{$\begin{array}{c}\mathrm{t}=0.62 \\
\mathrm{p}=0.538\end{array}$} & \multicolumn{2}{|c|}{$\begin{array}{c}\mathrm{t}=0.86 \\
\mathrm{p}=0.395\end{array}$} & \multicolumn{2}{|c|}{$\begin{array}{c}\mathrm{t}=1.42 \\
\mathrm{p}=0.068\end{array}$} & \multicolumn{2}{|c|}{$\begin{array}{l}\mathrm{t}=0.014 \\
\mathrm{p}=0.885\end{array}$} & $\begin{array}{l}\mathrm{t}=0.0 \\
\mathrm{p}=0.4\end{array}$ & & $\begin{array}{l}\mathrm{t}=0 \\
\mathrm{p}=0\end{array}$ & \\
\hline Presence of physic & ness & & & & & & & & & & & & & & \\
\hline Yes & 5 & 81.8 & 17.18 & 29.4 & 3.2 & 7.8 & 3.19 & 2.8 & 3.89 & 3.4 & 5.07 & 5 & 4.06 & 33.4 & 11.41 \\
\hline No & 34 & 77.84 & 37.3 & 25.12 & 13.84 & 9.24 & 5.08 & 4.57 & 4.27 & 7.36 & 8.51 & 4.03 & 3.3 & 27.51 & 13.35 \\
\hline & & $\begin{array}{r}\mathrm{t} 0 . \\
\mathrm{p}=0\end{array}$ & & $\begin{array}{r}\mathrm{t}=0 . \\
\mathrm{p}=0 .\end{array}$ & & $\begin{array}{l}\mathrm{t}=0 . \\
\mathrm{p}=0\end{array}$ & & $\begin{array}{l}\mathrm{t}=0 . \\
\mathrm{p}=0 .\end{array}$ & & $\begin{array}{r}\mathrm{t}=1 \\
\mathrm{p}=0\end{array}$ & & $\begin{array}{l}\mathrm{t}=0.0 \\
\mathrm{p}=0.5\end{array}$ & & $\begin{array}{l}\mathrm{t}=0 \\
\mathrm{p}=0\end{array}$ & \\
\hline Presence of menta & rder & & & & & & & & & & & & & & \\
\hline Yes & 5 & 90.68 & 36.64 & 31.4 & 6.5 & 9.4 & 3.97 & 6.4 & 6.06 & 14,8 & 17.48 & 7.8 & 1.78 & 37 & 13.05 \\
\hline No & 34 & 72.67 & 33.88 & 24.52 & 13.47 & 9.08 & 4.99 & 3.91 & 3.9 & 5.47 & 5.32 & 3.5 & 3.22 & 26.17 & 13.44 \\
\hline & & $\begin{array}{r}\mathrm{t}=2 \\
\mathrm{p}=0\end{array}$ & & $\begin{array}{r}\mathrm{t}=1 . \\
\mathrm{p}=0 .\end{array}$ & & $\begin{array}{r}\mathrm{t}=0 \\
\mathrm{p}=0\end{array}$ & & $\begin{array}{l}\mathrm{t}=1 \\
\mathrm{p}=0 .\end{array}$ & & $\begin{array}{r}\mathrm{t}=2 \\
\mathrm{p}=0 .\end{array}$ & & $\begin{array}{r}\mathrm{t}=2.8 \\
\mathrm{p}=0.0\end{array}$ & & & \\
\hline
\end{tabular}




\section{DISCUSSION}

The supportive care need scores of the patients, and thus their need levels were found to be high in the study conducted to determine the supportive care needs of individuals diagnosed with cancer. Miniotti et al. found that the supportive care need scores of the patients diagnosed with cancer were high ${ }^{25}$. Cancer is a growing health problem all over the world and it has been stated that 18.1 million people were added to new cancer cases in 2018, 9.6 million people died due to cancer ${ }^{26}$, and $50 \%$ of all cancer cases affected individuals over 65 years of age ${ }^{42}$. Of the patients participated in the study, $56.2 \%$ were male, $53.8 \%$ were in the $60-80$ age group and these values are consistent with current data on cancer epidemiology.

In the study in which approximately one third of the patients were diagnosed with GIS cancers and half of them were in the fourth stage, the fact that the patients reported that they were most concerned about nutrition / diet and that they wanted to get information about this subject can be thought to be related to the patients' being predominantly diagnosed with GIS cancers and to disease stage. Nausea-vomiting, anorexia, oral / gastrointestinal mucositis, dysphagia, diarrhea, constipation, tastesmell changes, weight gain / loss, malaise, fatigue, and malnutrition often develop in the patients receiving anti-cancer treatment ${ }^{27}$. The European Society for Clinical Nutrition and Metabolism (ESPEN) recommends frequent assessment of nutritional status in cancer patients and early initiation of nutritional support to the patients in need ${ }^{28}$.

Although very few (2.5\%) of the patients participated in the study stated that they had sexual problems, all of the patients stated that they did not want to get information about sexuality. It is reported that patients diagnosed with cancer experience varying degrees of sexual problems ${ }^{29}$, $72.1 \%$ of men receiving cancer treatment and $53.1 \%$ of women do not receive any help for their sexual problems ${ }^{30}$. Within the patient-centered care approach, the nurse has important responsibilities in identifying physical and psychological problems caused by cancer diagnosis and treatment and helping individuals with sexual problems ${ }^{31}$. When evaluating individuals with cancer, the approach to sexual dysfunction problems should be based on cultural characteristics, and supportive care interventions should be planned without disregarding sexuality, even if signs of sexual dysfunction are not detected.
In the study, "the uncertainty of the disease process, whether it would improve or not, the possibility of recurrence" were expressed as the most distressing conditions by the patients. Bernardes et al. determined that $46 \%$ of the individuals needed supportive care in physical and psychological dimensions and 23\% stated lack of information about the process in their study including cancer patients predominantly in the 60-80 age range ${ }^{32}$. It was determined that the rate of unmet needs of the patients was high and the most commonly stated need among the unmet needs by the patients was the need "to get information about the disease" in other studies conducted with patients undergoing cancer treatment ${ }^{33,34,35}$. The results obtained in this study are similar to previous study results.

It was found that the scores of female patients participated in the study were significantly higher in healthcare decision-making/communication subscale $(\mathrm{p}<0.05)$, and that women experienced more distress than men. The results of similar studies also show that the distress level experienced by women is higher than that of men ${ }^{36,37}$. In a similar study by Boyes et al., distress was found to be higher in women diagnosed with cancer 38

The total score of the James Supportive Care Screening was found to be higher in patients who stated that they had low income. Cancer may have caused the person to lose his/her job or the individual may be experiencing economic difficulties due to the costs incurred by the cancer treatment and care process. The area where the patients have needs most was reported to be in connection with experiencing economic difficulties in the study by Bernardes et al. with individuals diagnosed with cancer ${ }^{32}$ while unmet psychosocial needs of cancer patients with low income were reported to be higher in the study by $\mathrm{Yi}^{39}$. In a study conducted by Foster et al. with individuals diagnosed with cancer for 5 years or longer, it was stated that cancer patients experienced intense economic difficulties ${ }^{40}$.

It was determined that the support needs of the patients who stated that they had mental health problems besides the diagnosis of cancer were significantly higher in the social/practical problems and cognitive concerns subscales. In another study, it was determined that the scores of the patients who stated that they had mental health problems in addition to cancer were higher in the physical symptoms subscale ${ }^{41}$. After the diagnosis of cancer, the possibility of any depressive disorder in the patient was described as 40 percent and the 
most common mental disorder in cancer patients was reported to be depression ${ }^{42}$. In the study of Braamse et al., anxiety and depression levels of individuals diagnosed with cancer were found to be high ${ }^{43}$.

In this study, it was found that married individuals diagnosed with cancer had higher scores in all subscales except cognitive concerns and the total scores of supportive care needs, compared to single individuals diagnosed with cancer, and their need levels were higher in the mentioned areas. It can be concluded for this study that being married is more ineffective than expected in meeting the supportive care needs of individuals with cancer diagnosis. In a study conducted in the literature, the supportive care needs of married cancer patients were found to be at high levels ${ }^{35}$.

\section{CONCLUSION}

In our study in which the majority of the participants were male and individuals between the ages of 60-80, the supportive care needs of the patients were found to be high. Considering that cancer affects the individual in all its aspects, having a disorder in addition to cancer also increased the need level. The cancer patients may experience forced changes in their lives depending on the disease or processes as well as experiencing uncertainty, fear, anxiety and worry about staying in the hospital throughout the disease process. Lack of information about these conditions and educational needs to be met may arise. As nurses aiming at using holistic perspective in the provision of the care to be given to patients, knowing the care needs of cancer patients, identifying the risky and disadvantaged groups and meeting the educational needs are important in terms of putting the individual-specific and patient-based care approach into practice.

\section{REFERENCES}

1. Australian Government Cancer Australia, 2013 Address: https://canceraustralia.gov. au/system/tdf/publications/pcac-cancer-howare-youtravelling_504af0263f9c9.pdf?file $=1 \&$ type $=$ no de\&id=2846 Retrieved October 29, 2019

2. Harrison JD, Young JM, Price MA, Butow PN $\&$ Solomon MJ. What are the unmet supportive care needs of people with cancer? A systematic review. Supportive Care in Cancer, 2009, 17(8), 1117-1128.

3. Richardson A, Medina J, Brown V, Sitzia J. Patients' needs assessment in cancer care: a review of assessment tools. Support Care in Cancer ,2007, 15, 1125-1144.
4. Urbaniec OA, Collins K, Denson LA \& Whitford HS. Gynecological cancer survivors, Assessment of psychological distress and unmet supportive care needs. Journal of Psychosocial Oncology,2011, 29(5), 534-551.

5. Ream E, Quennell A, Fincham $L$ et al. Supportive care needs of men living with prostate cancer in England: a survey. British Journal of Cancer, 2008, 17, 98(12), 1903-9.

6. Ford E, Catt S, Chalmers A \& Fallowfield L. Systematic review of supportive care needs in patients with primary malignant brain tumors. Neuro-Oncology, 2012, 14(4), 392-404.

7. Institute of Medicine. Cancer care for the whole patient: meeting psychosocial concerns. The National Academic Press, Washington DC,2008

8. Miller BE, Pittman B, Strong C. Gynecologic cancer patients' psychosocial needs and their views on the physician's role in meeting those needs. International Journal of Gynecological Cancer,2003, 13, 111-119.

9. National Comprehensive Cancer Network, 2012, Address: https://www.nccn.org/patients/resources/life_w ith_cancer/distress.aspx Retrieved November 1, 2019

10. Giraldi T, De Vanna M, Malagoli $M$ et al. Mental adaptation to cancer: depression and blood platelet monoamineoxidase activity in breast cancer patients. Anticancer Research; 2007, May-Jun. 27 (3b).

11. Yıldırım KN, Kaçmaz N, Özkan M. İleri evre kanser hastalarının karşılanmamış gereksinimleri. Psikiyatri Hemşireliği Dergisi;2013, 4(3), 153-8.

12. National Cancer Nursing Education Project, 2015,

Address:http://edcan.org.au/assets/edcan/files/c ancer-care-coordinator-position-

statement_final-endorsed-by-

council_161115_cnsa-logo.pdf__ Retrieved October 29,2019

13. Multionational association of supportive care in cancer

Address:https://www.mascc.org/assets/Guideli nesTools/guidelines_mucositis_turkish.pdffile: ///C:/Users/a/Downloads/23-1816-1-PB.pdf Retrieved October 29, 2019

14. Rankin NM, Barron JA, Lane LG, Mason CA, Sinclair S, Bishop JF Psychosocialoncologyservices in New South Wales. AustHealthRev, 2011, 35:156-163 
15. Gardner RB. A holistic assessment of the perceived supportive care needs of cancer patients during treatment. University of New Orleans Theses and Dissertation, 2008, Paper 823.

16. Howell D, Mayo S, Currie S, Jones G, Boyle M. et al. Psychosocial health care needs assessment of adult cancer patients: a consensus-based guideline. Support Care Cancer, 2012, 20(12), 3343-54.

17. Gregorio S, Porensky E, Minotti M, Brown S, Janet $S$. et al. The James supportive care screening: İntegrating science and practice to meet the NCCN guidelines for distress management at a comprehensive cancer center. Psychooncology ; 2013, 22(9), 1-17.

18. Cancer Australia, Clinical Best Practice Address:https://canceraustralia.gov.au/clinicalbest-practice/cancer learning/communicationskills-training Retrieved October 29, 2019

19. Steele R, \& Fitch M I. Supportive care needs of women with gynecologic cancer. Cancer Nursing,2008, 31(4), 284-291.

20. Maguire R, Papadopoulou C, Kotronoulas G, Simpson MF, McPhelim J, et al. A systematic review of supportive care needs of people living with lung cancer. European Journal of Oncology Nursing,2013, 17, 449-64.

21. Agecare, England Address: http://www.agecare.org/publications.asp Retrieved October 29, 2019

22. Polikandrioti M, Ntokou M. Needs of hospitalized patients. Health Science Journal, 2011, Volume 5, Issue 1, 15-22.

23. Işık I. Meme kanseri hastalarında tedavi sonrası dönemde gelişen psikososyal sorunlar ve destekleyici hemşirelik girişimleri, Hemşirelikte Eğitim Ve Araştırma Dergisi 2014;11 (3), 58-64.

24. Demirkol H, Çam MO. Kanser hastalarında James destekleyici bakım gereksinimlerini belirleme ölçeği'nin geçerlik ve güvenirlik çalışması, 2016, Ege Üniversitesi Sağlık Bilimleri Enstitüsü, Psikiyatri Hemşireliği Program1, Yüksek Lisans Tezi.

25. Miniotti M, Bassino S, Fanchini L, Ritorto G, \& Leombruni P. Supportive care needs, quality of life and psychological morbidity of advanced colorectal cancer patients. European Journal of Oncology Nursing,2019, 43, 101668.
26. World Health Organization, Address: https://www.who.int/cancer/PRGlobocanFinal. pdf_Retrieved October 29, 2019

27. Sobotko L. Klinik Nütrisyonun Temelleri Dördüncü Bask1 (H.Gündoğdu Çev.Ed). Kanser hastalarında nütrisyonel destek ve kanser kaşeksisi. Ankara: Bayt Bilimsel Yayınlar, 2013:573-591.

28. Arends J, Bachmann P, Baracos V. ESPEN guidelines on nutrition in cancer patients. Clin Nutr. 2017, 36:11-48.

29. Olsson C, Berglund AL, Larsson M, Athlin E. Patient's sexuality - a neglected area of cancer nursing. European Journal of Oncology Nursing , 2012, 16, 426-31.

30. Moreira EDJ, Glasser DB, Gingell C.Sexual activity, sexual dysfunction and associated help-seeking behaviours in middle-aged and older adults in Spain: a population survey. World J Urol. 2005, 23: 422-429.

31. Pinar G. Kanser tedavisi alan hastalarda cinsel disfonksiyon ve danışmanlığa ilişkin hemşirelik yaklaşımları, Gülhane Tıp Derg. 2010, 52: 241247.

32. Bernardes CM, Diaz A, Valery PC, Sabesan S, Baxi S. Unmet supportive care needs among Indigenous cancer patients across Australia. Rural and Remote Health; 2019, 19: 4660.

33. Ng R, Verkooijen HM, Ooi L L, \& Koh WP. Unmet psychosocial needs among cancer patients undergoing ambulatory care in Singapore. Supportive Care in Cancer, 2011, 20(5), 1049-1056.

34. Mawardika T, Afiyanti $\mathrm{Y}$, Rahmah $\mathrm{H}$. Gynecological cancer inpatients need more supportive nursing care than outpatients: a comparative study. BMC Nurs. 2019, 16;18(Suppl 1):28.

35. Hui D. Definition of supportive care: does the semantic matter? Curr. Opin. Oncol. 2014, 26, 372-379

36. Herschbach P, Book K, Brandl T. et al Psychological distress in cancer patients assessed with an expert rating scale. British Journal of Cancer, 2008, 99(1), 37-43.

37. Aranda S, Schofield P, Weih L. et al. Mapping the quality of life and unmet needs of urban women with metastatic breast cancer. Eur J Cancer Care (Engl), 2005, 14:211-22.

38. Boyes AW, Girgis A, D'Este C, Zucca AC. Prevalence and correlates of cancer survivors' supportive care needs 6 months after diagnosis: 
a population-based crosssectional study. BMC Canc.2012, 12, 150.

39. Yi M, Park K, Park YE. Psychosocial needs of low-income people with cancer in Korea. European Journal of Oncology Nursing, 2014, 18, 549- 56.

40. Foster C, Wright D, Hill H, Hopkinson J, Roffe L. Psychosocial implications of living 5 years or more following a cancer diagnosis: a systematic review of the research evidence. Eur J Cancer Care, 2009, 18(3):223-47.

41. Mohammadzadeh Nimekari M, Saei Ghare Naz M, Ashouri Taziani Y.__Correlation between Supportive Care Needs of Women with Breast Cancer and Quality of Life of their Family Caregivers. Int J Community Based Nurs Midwifery.2019, 7(4):300-308.

42. TC Sağlık Bakanlığı Tedavi Hizmetleri Genel Müdürlüğü. Türkiye Onkoloji Hizmetleri Yeniden Yapılanma Programi 2010- 2023. Ankara, T.C. Sağlık Bakanlığı, 2010

43. Braamse AM, van Turenhout ST, Terhaar Sive Droste JS. et al. Factors associated with anxiety and depressive symptoms in colorectal cancer survivors. Eur. J. Gastroenterol. Hepatol.2016, $28,831-835$ 